\title{
Gut microbiome, endocrine control of gut barrier function and metabolic diseases
}

\author{
Marion Régnier1, Matthias Van Hul1', Claude Knauf2,3 and Patrice D Cani(D1,3 \\ 1UCLouvain, Université Catholique de Louvain, WELBIO - Walloon Excellence in Life Sciences and BIOtechnology, Louvain Drug Research Institute, \\ Metabolism and Nutrition Research Group, Brussels, Belgium \\ 2Université Paul Sabatier, Toulouse III, INSERM U1220, Institut de Recherche en Santé Digestive (IRSD), CHU Purpan, Place du Docteur Baylac, Toulouse \\ Cedex 3, France \\ ${ }^{3}$ European Associated Laboratory (EAL) 'NeuroMicrobiota', Brussels/Toulouse, Belgium
}

Correspondence should be addressed to P D Cani: patrice.cani@uclouvain.be

This paper is part of a collection of articles exploring Gut Microbiome and Endocrinology, across the Journal of Endocrinology and the Journal of Molecular Endocrinology. The editor for this section was Dr Jonathon Schertzer.

\begin{abstract}
Overweight and obesity are associated with several cardiometabolic risk factors, including insulin resistance, type 2 diabetes, low-grade inflammation and liver diseases. The gut microbiota is a potential contributing factor regulating energy balance. However, although the scientific community acknowledges that the gut microbiota composition and its activity (e.g. production of metabolites and immune-related compounds) are different between healthy subjects and subjects with overweight/obesity, the causality remains insufficiently demonstrated. The development of low-grade inflammation and related metabolic disorders has been connected with metabolic endotoxaemia and increased gut permeability. However, the mechanisms acting on the regulation of the gut barrier and eventually cardiometabolic disorders are not fully elucidated. In this review, we debate several characteristics of the gut microbiota, gut barrier function and metabolic outcomes. We examine the role of specific dietary compounds or nutrients (e.g. prebiotics, probiotics, polyphenols, sweeteners, and a fructose-rich diet) as well as different metabolites produced by the microbiota in host metabolism, and we discuss how they control several endocrine functions and eventually have either beneficial or deleterious effects on host health.
\end{abstract}
Key Words
- obesity
- diabetes
- gut microbiota
- gut barrier

\section{Introduction}

Obesity is linked with many cardiometabolic risk factors, such as insulin resistance, type 2 diabetes, and nonalcoholic fatty liver disease (NAFLD). Although lowering body weight is effective for alleviating several of these metabolic abnormalities, prevention remains the greatest challenge. Among the different factors contributing to the regulation of energy balance, the microorganisms that reside in the human gut (called the gut microbiota) have received increasing attention. Initially, the gut microbiota was studied because of its association with classical infectious diseases, such as gut infections (Escherichia coli, Shigella), acute colitis, Crohn's disease, and inflammatory bowel disease (IBD) (Macpherson \& Harris 2004, Voth \& Ballard 2005, Frank et al. 2007, Lupp et al. 2007), but in the last 2 decades, it has been investigated also because of functions beyond those of pathogens (Backhed et al. 
2004, Cani \& Delzenne 2009). This incredible awareness of the potential of the gut microbiota is translated by more than 5000 publications in 2019 alone, many of which are dedicated to the study of the gut microbiota and cardiometabolic disorders associated with overweight and obesity. However, caution must be taken with regard to the causality raised in the literature (Lynch \& Pedersen 2016, Cani 2017, 2018). In this review, we specifically discuss different aspects of the link between the gut microbiota, gut barrier function and metabolic outcomes. We discuss the role of different metabolites produced by the microbiota in host metabolism and how specific nutrients may promote either beneficial or deleterious effects on host health.

\section{Role of microbiota in the onset of metabolic diseases}

In 2004, pioneering work from Jeffrey Gordon and his team showed that mice lacking a microbiota (i.e. germ-free mice) were characterized by specific energy metabolism and even resistance to diet-induced obesity (Backhed et al. 2004, 2007). In the same period, we identified a causal association between the gut microbiota and the development of low-grade inflammation and insulin resistance associated with obesity and lipid-rich diets (i.e. a high-fat diet, HFD) (Cani et al. 2007). We found that some constituents of gram-negative bacteria, such as lipopolysaccharides (LPS), were the key factors triggering the onset of low-grade inflammation and insulin resistance (Cani et al. 2007). By using different animal models (i.e. genetic, diet-induced obesity and diabetes models), we discovered that these animals had an increased level of circulating LPS, a condition termed metabolic endotoxaemia (Cani et al. 2007). This finding has since been confirmed in several human studies (Amar et al. 2008, Gummesson et al. 2011, Lassenius et al. 2011, Laugerette et al. 2011, Monte et al. 2012, Pussinen et al. 2011, Horton et al. 2014, Jayashree et al. 2014, RadillaVazquez et al. 2016, Gomes et al. 2017) (Fig. 1). Since this discovery, other pathogen-associated molecular patterns (PAMPs) (e.g. flagellin and peptidoglycans) have also been shown to play a fundamental role in the regulation of similar metabolic pathways (Vijay-Kumar et al. 2010, Chassaing et al. 2014, Denou et al. 2015). Over the years, thriving literature has demonstrated that alterations in gut microbiota composition and function are widely associated with the development of metabolic diseases, especially obesity and type 2 diabetes (T2D), in humans (Cotillard et al. 2013, Karlsson et al. 2013, Le Chatelier et al. 2013, Pedersen et al. 2016). In this context, faecal microbiota transplantation (FMT) has recently emerged as a good option to assess the causal relationship between the gut microbiota and the onset of metabolic diseases (Vrieze et al. 2012, Le Roy et al. 2013, Kootte et al. 2017). In addition, an increasing number of studies are seeking to identify specific microbial signatures in the gut and liver that could predict the onset and/or severity of metabolic disorders, such as liver diseases (Michail et al. 2015, Boursier et al. 2016, Wang et al. 2016, Sookoian et al. 2020). In addition to changes in the gut microbiota, it was discovered that the barrier function of the gut also played a key role (for a review: Cani 2018, Cani et al. 2019). Because gut microbes are located close to intestinal epithelial cells, gut barrier function must be highly efficient to prevent the enteric microbiota and potent immunostimulatory molecules from entering the circulation. However, the gut barrier must also be permissible to allow uptake of essential nutrients and fluids. This delicate balance is part of a multifaceted system controlled through intricate mechanisms. Over the last decade, the role of gut barrier function has been investigated, and numerous studies have discovered that maintaining an adequate gut barrier requires finely tuned mechanisms that are dependent on the microbial composition. More precisely, the gut barrier is composed of several physical and chemical components. A single layer of epithelial cells that display densely packed microvilli (brush border) and are joined at their apical side by tight junction proteins (TJPs,e.g. zonula occludens 1 (ZO-1), occludin, and claudins) act as the transcellular barrier. This monolayer is renewed constantly (every 4-5 days due to Intectin and Cyclin D1) and is covered by a protective mucus layer that is impregnated with several immune factors (e.g. antimicrobial factors) produced by the host. Together, the mucus layer and the different antimicrobial factors (e.g. C-type lectin, primarily regenerating islet-derived 3-gamma, $\operatorname{Reg} 3 \gamma$, several defensins, lysozyme $\mathrm{C}$ and phospholipases) contribute to maintaining gut microbes at a certain distance from intestinal epithelial cells (Hooper \& Macpherson 2010, Bevins \& Salzman 2011, Pott \& Hornef 2012) (Fig. 1). Maintaining the integrity of the gut barrier is critical and avoids structural and functional disorganization of the intestine that can lead to several disorders. IBD is the hallmark example of compromised gut barrier function (Wehkamp et al. 2008, Stange \& Schroeder https://joe.bioscientifica.com

https://doi.org/10.1530/JOE-20-0473 (c) 2021 Society for Endocrinology Published by Bioscientifica Ltd. Printed in Great Britain 


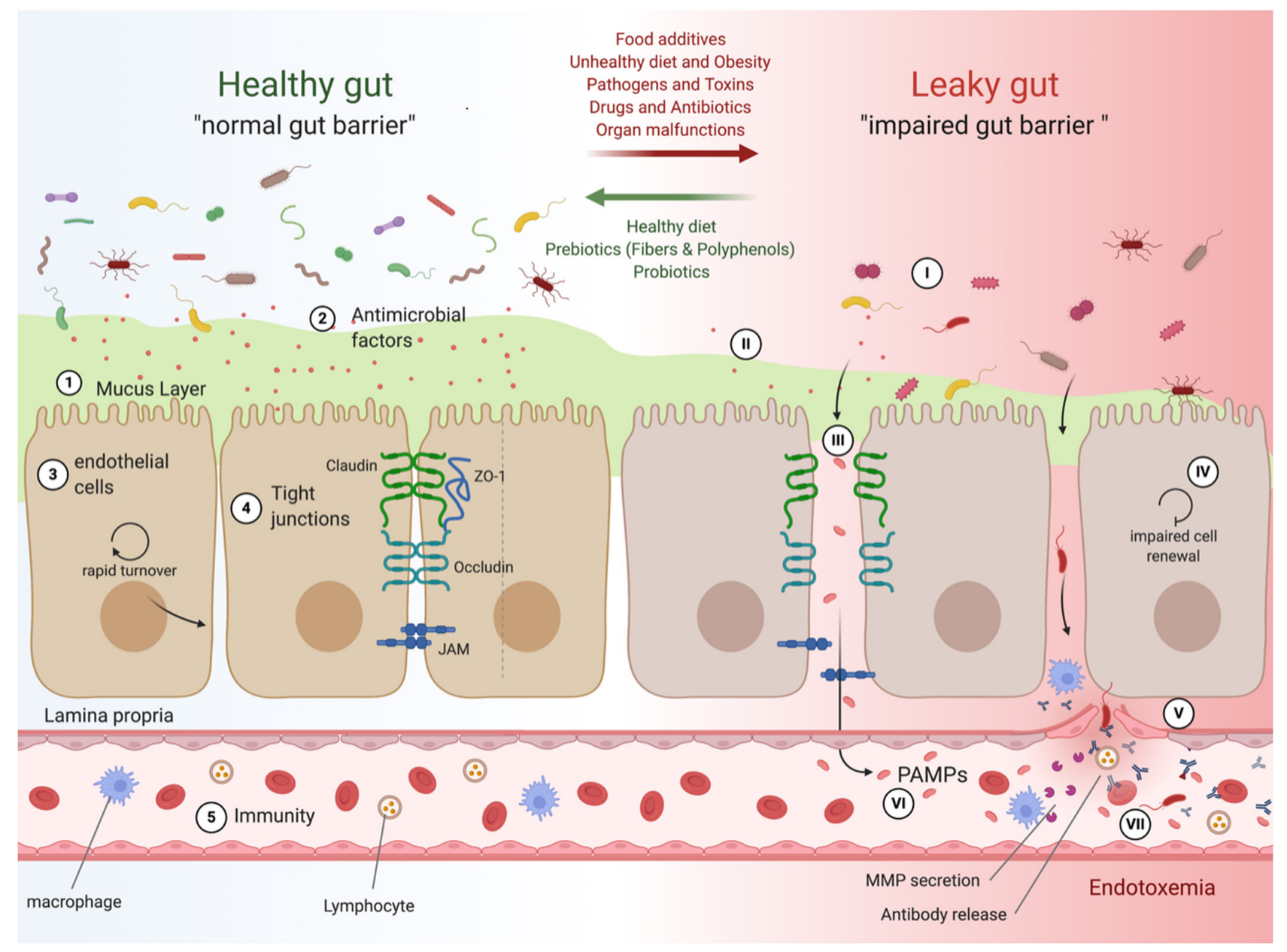

\section{Figure 1}

The gut barrier is composed of several physical and chemical components The mucus layer (1) acts as a physical barrier to keep the local microbiota at a distance. It is impregnated with factors that provide additional antibacterial activity (2). Epithelial cells (3), joined together by tight junction proteins (4), are the primary gatekeepers and are renewed every 4-5 days. Immune cells (5) serve as the body's border patrol and limit the inner body's exposure to allergens, pollutants, viruses, bacteria, and parasites. Disruption of the gut barrier (right) is associated with alterations in microbiota composition (I), reduction in mucus layer thickness and consistency (II), disruption of TJPs (III), impaired cell renewal (IV), increased permeability (V), translocation of PAMPS and pathogens (endotoxaemia) (VI) and inflammation (VII). ZO-1, Zonula occludens-1; JAM, junctional adhesion molecule; PAMPs, pathogenassociated molecular patterns; MMP, matrix metalloproteinase.

2019). Altered mucus function and chemical defence by defensins are characteristic of ulcerative colitis and Crohn's disease, respectively (Salzman et al. 2010, Johansson et al. 2014). It is important to note that the antibiotic action of specific defensins is reinforced by their proteolytic fragmentation into shorter peptides and thereby constitutes an interesting way to modulate gut barrier function (Ehmann et al. 2019). Defects in this line of defence have also been correlated with metabolic diseases. By using metaproteomic resources, Zhang et al. showed that several AMPs are depleted in the faeces of T2D subjects in comparison to those in prediabetic and healthy subjects (Zhong et al. 2019). In addition to the innate immune system, the adaptive immune system is another important contributor; for example, immunoglobulin A ( $\operatorname{Ig} \mathrm{A})$ is able to inhibit bacterial penetration into the host mucus and mucosal tissue (Macpherson et al. 2012).

Therefore, gut barrier function is a very complex and multifaceted mechanism (Fig. 1), and alterations in this line of defence are the first signal that allows the penetration of bacteria and thereby contributes to a local inflammatory response (e.g. IBD) and/or metabolic disorders (e.g. T2D) (reviewed in Konig et al. 2016, Wells et al. 2017, Stange \& Schroeder 2019, Paone $\&$ Cani 2020). https://joe.bioscientifica.com https://doi.org/10.1530/JOE-20-0473
(C) 2021 Society for Endocrinology Published by Bioscientifica Ltd. Printed in Great Britain 


\section{Effect of specific nutrients on the microbiota composition and their impact on health 'beneficial' vs 'deleterious' effects}

Maintaining normal intestinal barrier function is an essential aspect of human health. The growing significance of gut barrier integrity and concomitant translocation of bacteria and bacterial components raises the question of how we can improve gut barrier function. This aspect is of particular interest since alteration of intestinal homeostasis (gut microbiota composition and gut barrier function) directly or indirectly (via microbial-produced metabolites) disturbs the production and secretion of gut endocrine hormones, thereby triggering metabolic diseases (Fig. 2). The most obvious strategy to maintain gut barrier integrity is to maintain a healthy nutritional status, as it has been shown that certain dietary patterns are associated with improved health (e.g. a Mediterranean vs Western diet), whereas high-fat, high-sugar diets or diets depleted of certain nutrients, such as zinc, glutamine and tryptophan, could compromise gut barrier integrity (see below the section deleterious effects).

Dietary patterns are dominant factors in shaping the gut microbiota. Therefore, understanding the key mechanisms involving the different components of our diet are a challenge that needs to be met. Effectively manipulating the microbiota can reduce low-grade intestinal inflammation and improve gut barrier integrity, thereby reducing plasma glucose and serum lipid levels, ultimately resulting in weight loss and decreased insulin resistance (Dray et al. 2007, Cani et al. 2009a, Parnell
\& Reimer 2009, Dewulf et al. 2013). This constitutes a promising and feasible approach, and several dietetic concepts, including prebiotics as well as probiotics, are currently being researched (Reid et al. 2019, Sanders et al. 2019). Traditionally, the quality and quantity of fatty acids and dietary fibres are denoted as crucial modulators of the gut microbiota composition (Devkota et al. 2012, Caesar et al. 2015, Lam et al. 2015, Just et al. 2018, Makki et al. 2018); however, it is now clear that other potential actors, including many different metabolites, are involved (Wikoff et al. 2009, Holmes et al. 2011, Zierer et al. 2018). In the next section of this review, we will focus on specific nutrients or food additives that are currently used in the Western diet. We focus first on the 'beneficial' factors and then the 'deleterious' factors.

\section{Beneficial effects}

\section{Gut permeability and prebiotics}

Since the beginning of the 2000s, the expansion of original scientific work has tended to show that the modulation of the gut microbiota population by prebiotics has a major impact on human health (Roberfroid et al. 2010). This is particularly the case for fermentable dietary fibres, such as inulin-type fructans that include inulin and oligofructose (Gibson et al. 2017), which are known to improve glucose homeostasis (Cani et al. 2006, Roberfroid et al. 2010). Evidence suggests a potential link between the intake of prebiotics and the modulation of gut permeability. The increased use of prebiotics to improve insulin sensitivity

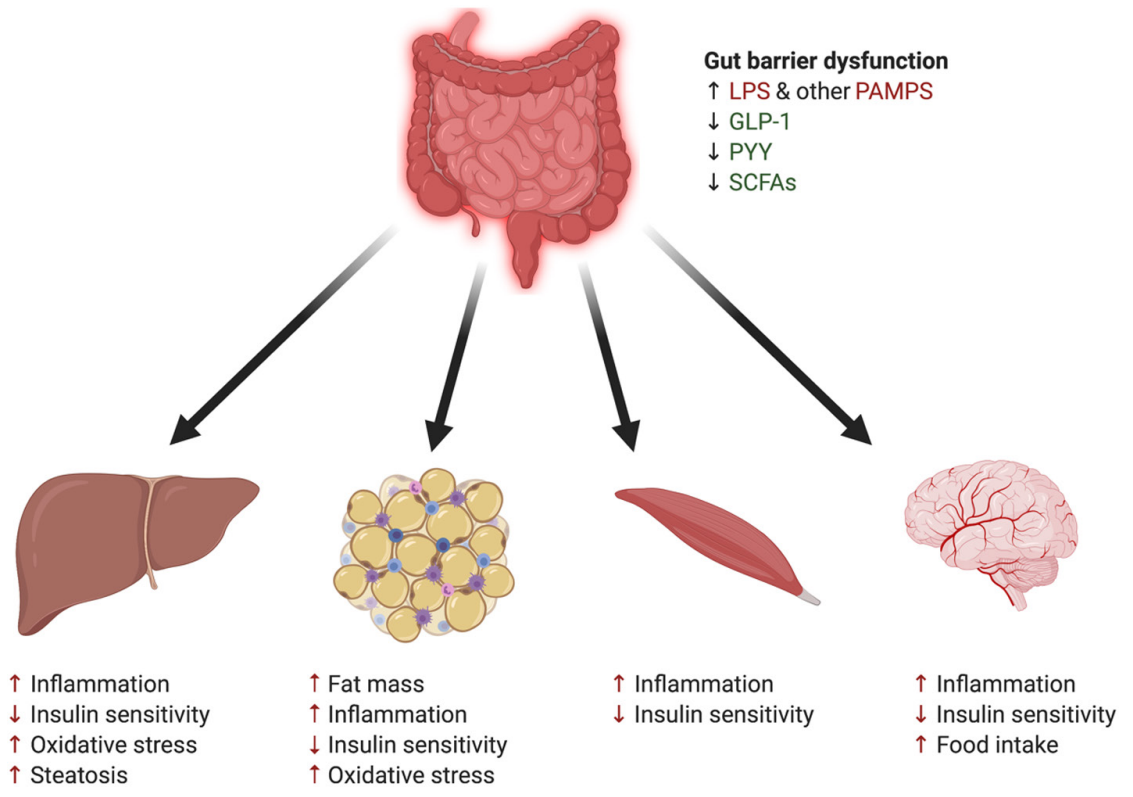

Figure 2

Gut barrier dysfunction has systemic consequences. Disruption of the gut barrier leads to metabolic endotoxaemia and impaired production of circulating gut hormones. This phenomenon translates to metabolic disorders in various organs. https://joe.bioscientifica.com https://doi.org/10.1530/JOE-20-0473 (c) 2021 Society for Endocrinology Published by Bioscientifica Ltd. Printed in Great Britain 
and/or reduce food intake in metabolic disorders is well described in animal models and in humans (reviewed in Delzenne et al. 2011).

\section{Animal models}

Deciphering the mode of action of prebiotics on insulin sensitivity or energy homeostasis is still a competitive research topic. In 2004, we discovered that the colonic fermentation of a specific prebiotic called oligofructose (i.e. an inulin-type fructan) had the capacity to modulate endogenous production of appetite-controlling gut hormones (Cani et al. 2004). Indeed, both oligofructose and inulin have the capacity to reduce dietary intake in rodents by a mechanism that involves anorexigenic and orexigenic gut hormones, that is, an increase in glucagon-like peptide 1 (GLP-1) and peptide YY (PYY) concentrations in the intestine and a decrease in the orexigenic hormone ghrelin concentration (Cani et al. 2004, Delzenne et al. 2005). Prebiotics are generally known for their health benefits, but some recent papers bring nuances to the debate. Singh et al. showed that mice fed a compositionally defined diet (CDD) enriched with inulin developed hepatocellular carcinoma (HCC) through a mechanism dependent on the gut microbiota (Singh et al. 2018). These results are in line with another study showing that inulin, when incorporated into a CDD, exacerbated colitis in mice exposed to dextran sulphate sodium (DSS) (Miles et al. 2017). Although this effect has been observed in very specific animal models, these findings prove the importance of the dietary context in the effects of prebiotics in general. Regarding their mechanisms of action, many questions remain, but it is well known that due to their utilization by specific bacteria (i.e. fermentation), prebiotic fibres are transformed into different bacterial metabolites, such as short-chain fatty acids (SCFAs) (Koh et al. 2016). These SCFAs act on a specific family of G-coupled protein receptors (GPCRs) called GPR41 and GPR43 (Le Poul et al. 2003) and trigger the secretion of gut peptides involved in the regulation of appetite, energy homeostasis and glucose metabolism (Brooks et al. 2017). However, this mechanism is still debated since Zou et al. showed that SCFAs and GPR43 are dispensable in the beneficial effects of inulin on HFD-induced low-grade inflammation and metabolic syndrome (Zou et al. 2018). They demonstrated that IL-22, which is already known to protect against several intestinal infections (Zheng et al. 2008, Zhong et al. 2019), is involved in fortification of the intestine through increased epithelial cell proliferation, thus contributing to protection against HFD-induced disorders.
In 2006, we demonstrated that the anti-diabetic action of oligofructose required a GLP-1 signalling pathway. Indeed, blocking the GLP-1 receptor by using pharmacological agents or using GLP-1 receptor knockout mice abolished the anti-diabetic effect of oligofructose (Cani et al. 2006). Treatment of obese and diabetic mice with oligofructose is associated with changes in the gut microbiota that rescue intestinal permeability. This physiological effect is associated with a restoration of the distribution and localization of the TJPs ZO-1 and occludin, thereby reinforcing the gut barrier, decreasing the LPS concentration in the portal vein and eventually reducing hepatic steatosis and systemic inflammation (Cani et al. 2009b, Everard et al. 2011). Importantly, blocking the GLP-2 receptor, a gut peptide increased by prebiotics and regulating epithelial cell proliferation and the gut barrier, abolished the effects of prebiotics on the gut barrier. This last result shows that prebiotics have the capacity to reduce low-grade inflammation and contribute to reducing insulin resistance. In addition, mice lacking the receptor GPR43 do not respond to prebiotic fibres, thereby showing the link between SCFAs, specific gut peptides and metabolism (Brooks et al. 2017). However, recent data also suggest that not all fermentable dietary fibres exert their effects on either the gut barrier or glucose metabolism by similar mechanisms and likely not only via SCFAs and gut peptides (Van Hul et al. 2020). Indeed, the reduction in HFD-induced obesity, fat mass accumulation and glucose intolerance with oligofructose and soluble corn fibre involves a distinct remodelling of the gut microbiota and subsequent different SCFA profiles.

Therefore, although some mechanisms of action have been identified, it has also been established that gut microbes exert other functions via, for example, the release of other biological factors (such as neurotransmitters, bioactive lipids, gases) that also have an impact on gut physiology and contribute to the cross-talk observed between gut microbes and the host (review in Cani \& Knauf 2016, Rastelli et al. 2018, 2019).

\section{Humans}

Although numerous data have been obtained in animals, human data also support that changing the gut microbiota by using fermentable fibres modifies gut peptide production (i.e. GLP-1, PYY, and Ghrelin) (Cani et al. 2009a, Parnell \& Reimer 2009). Other studies have also confirmed the key role played by SCFAs in the beneficial effects, suggesting that they may be due to increased plasma levels of the enteroendocrine hormones PYY and GLP-1 (Freeland \& Wolever 2010, Chambers et al. 2015). 
In addition to their effects on gut peptides, inulin-type fructans exert beneficial effects on glucose metabolism in humans, including an improvement in fasting glycaemia, hyperinsulinaemia, HOMA-IR and HbA1c (Rao et al. 2019, Zhang et al. 2020). Several recent studies also found that a mix of prebiotics (i.e. inulin/oligofructose) correlated with bacterial-related metabolites (phosphatidylcholine, lactate and others) and to a specific gut microbiota composition that could explain the beneficial effect on glucose metabolism (Dewulf et al. 2013, Hiel et al. 2019, Rodriguez et al. 2020).

The results obtained regarding satiety and food intake are more discussed in humans. In 2018, Korczak and Slavin showed that fructan fibres used at a dose less than $10 \mathrm{~g} /$ day did not modify satiety or food intake (Korczak \& Slavin 2018). The authors claimed that these fibres could not be used as the sole satiating agent since their impact on food intake is observed only at very high doses ( $>16 \mathrm{~g} /$ day) and when used for a long period (12-16 weeks).

Overall, the impacts of prebiotics on food consumption, glucose metabolism and body weight in humans are less significant than those observed in rodents.

\section{Gut permeability and polyphenols}

In addition to dietary fibres, plant-derived polyphenols represent other important substrates for the gut microbiota. Like dietary fibres, they are catabolized by and may influence the intestinal microbial ecosystem. In recent decades, polyphenols and their metabolites have gained attention for their promising beneficial health effects, which are generally attributed to their antimicrobial, antioxidant and anti-inflammatory properties (Anhe et al. 2019). Recent studies also show the role of plant polyphenols in the regulation of the intestinal barrier. An overview of the main evidence from in vitro and in vivo studies supporting the role of polyphenols in modulating gut barrier permeability was the subject of a recent publication and will not be repeated here (Bernardi et al. 2020). At present, it remains largely unknown how polyphenols exert their beneficial effects. They may be mediated by the microbial production of bioactive polyphenol-derived metabolites and/or by the modulation of the gut microbial community itself. However, several hypotheses have been proposed regarding how polyphenols influence the gut barrier. For example, polyphenols may improve barrier function by regulating oxidative stress through the downregulation of reactive oxygen species (ROS). Another mechanism by which polyphenols could exert their activity is by targeting different members of the NF-kB pathway or by antagonizing its activation. This pathway is responsible for the transcriptional induction of pro-inflammatory cytokines, chemokines and additional inflammatory mediators in different types of innate immune cells. By interfering with this signalling, polyphenols prevent the disassembly of TJPs and restore barrier integrity. Polyphenols also reinforce gut barrier function and morphology through the maintenance of the epithelial mucus layer in different mouse models of defective gut epithelium (Pierre et al. 2013, Rodríguez-Daza et al. 2020). However, many other pathways have also been suggested as potential polyphenol targets, many of which cross-talk with each other (reviewed in Yang et al. 2017), making this a complex issue to disentangle and highlighting the diversity within the polyphenol family. Indeed, in a comparative study using polyphenols derived from different sources (grapes or cinnamon), we demonstrated that both polyphenol extracts produced similar metabolic outcomes and that both improved gut barrier integrity via different underlying mechanisms (Van Hul et al. 2018).

When discussing the health-promoting effects of polyphenols, it is important to consider their phenolic composition, bioavailability, distribution, metabolism and elimination. All of these parameters vary importantly from one study to another and explain, among others, strong interindividual variations (Teng \& Chen 2019, Boccellino \& D'Angelo 2020). The composition of polyphenol-rich solutions (e.g. sugar, fibre, and impurities) is not fully known in preclinical and clinical studies, and it remains difficult to determine the exact contribution of polyphenols rather than other components to the observed effects. Therefore, some efforts need to be made to standardize the chemical forms of dietary polyphenols used in preclinical and clinical studies to fully assess the effect of polyphenols on gut barrier function and health.

\section{Deleterious effects}

\section{Impact of high-fat diets on the gut barrier}

Chronic excess dietary fat not only increases systemic exposure to potentially pro-inflammatory free fatty acids but also disrupts gut barrier function by several mechanisms. First, a HFD can directly increase gut barrier permeability because both saturated and unsaturated fatty acids can impair the expression and distribution of TJPs. Moreover, lipid-rich diets facilitate the physiological absorption of LPS via the formation of chylomicrons (Ghoshal et al. 2009). This phenomenon will trigger 
an immune response and enhance the secretion of pro-inflammatory factors (e.g. cytokines), which will then disrupt TJPs. This activity will in turn increase the permeability and leads to the leakage of even more LPS, resulting in a vicious circle (Yoshida et al. 2001, Fujiyama et al. 2007, Cani et al. 2008, Hamilton et al. 2015, Luck et al. 2015, Kawano et al. 2016, Zou et al. 2018). It has also been proposed that saturated fatty acids directly bind to toll-like receptor 4 (TLR-4) in the intestine via the adaptor protein fetuin A, thereby suggesting that saturated fatty acids may directly increase the production of inflammatory markers (Pal et al. 2012) and contribute to alteration of the gut barrier. In contrast, mucus integrity has been positively associated with fatty acid synthase (FAS), a ratelimiting enzyme of fat-producing lipogenesis (Wei et al. 2012). Defective intestinal lipogenesis in the absence of FAS is detrimental to the palmitoylation of Muc2, a key component of the mucus layer. These findings highlight the importance of lipid sources (dietary fat vs de novo synthetized fat) in gut barrier function.

The HFD has become the gold standard for the study of the relationship between gut function and obesity (Buettner et al. 2007). It is now well accepted that a HFD leads to alterations in gut microbiota composition and gut barrier function. However, caution should be exercised with regard to the composition of diets. The amounts of fibres, one of the main substrates used by the gut microbiota, differ among chow diets and are often greater than those found in HFDs (Pellizzon \& Ricci 2018). Pioneering studies were performed using fibrerich chow diets as a control and demonstrated for the first time that mice fed a HFD displayed increased gut permeability not only because of an alteration of TJPs but also because of an alteration of the intestinal mucus layer, further participating in gut barrier dysfunction and endotoxaemia (Cani et al. 2007, Everard et al. 2013, Gulhane et al. 2016). Since then, many works have been carried out with compositionally defined diets (CDDs) as a control, which mirror the composition of HFDs (excluding fat) (Chassaing et al. 2015b, Jensen et al. 2016, Dalby et al. 2017). While exposure to the CDD (vs chow diet) induced significant alterations in the gut microbiota composition and in the intestine morphology, this effect is not sufficient to induce obesity and glucose intolerance that are characteristic of HFD feeding, thereby suggesting that gut microbiota alterations do not necessarily determine the onset of obesity (Dalby et al. 2017).

In addition to the mechanisms described above, dietary fat may also induce gut barrier dysfunction via alteration of the luminal bile acid profile. For example, dietary fat increases the concentration of deoxycholic acid (DCA), which is very hydrophobic and capable of disrupting cell membranes, whereas it reduces the concentration of the more hydrophilic and membrane-stabilizing ursodeoxycholic acid (UDCA) (Stenman et al. 2012). In addition, BA has been shown to modulate gut permeability by affecting tight junction structure (Raimondi et al. 2008, Suzuki \& Hara 2010, Stenman et al. 2012). All these mechanisms support the notion that the HFD induces health disorders through an alteration of the gut environment.

\section{The effects of sweeteners}

In addition to the higher fat and sugar content, the Western-type diet is made up of ultra-processed food containing a large number of food additives (Carocho et al. 2014). Among them, sweeteners are widely present to make food more palatable and stable. Despite their approbation by regulatory agencies, artificial sweeteners are not all safe, and some of them present adverse health effects. Saccharin, sucralose and aspartame induced glucose intolerance more than glucose did (with saccharin having the most pronounced effect) through an alteration in the composition and function of the gut microbiota (Suez et al. 2014). Mice exposed to saccharine exhibited glucose intolerance associated with increased Bacteroides and decreased Clostridiales abundance. Metagenomic analysis revealed an enrichment in pathways targeting lipopolysaccharide biosynthesis, thereby revealing the potential mechanism by which sweeteners enhance susceptibility to T2D (Suez et al. 2014). In the same study, the authors demonstrated a positive correlation between the consumption of sweeteners and metabolic parameters such as HBA1c and glucose in humans. In another study that linked sweeteners with the gut microbiota, the authors reported that several 'beneficial' bacteria, such as Bifidobacterium, Lactobacillus and Bacteroides, were depleted in animals exposed to a combination of sweeteners and maltodextrin (Abou-Donia et al. 2008). Given that sweeteners are able to bind sweettaste receptors that are essential for the release of incretins, a large number of studies have aimed to investigate the potential of sweeteners as agents to trigger the secretion of gut endocrine hormones. Although sweeteners (mainly sucralose) have been reported to stimulate the release of GLP-1 in several enteroendocrine cell lines (Jang et al. 2007, Margolskee et al. 2007, Kidd et al. 2008, Geraedts et al. 2011), oral exposure in mice and humans failed to show the same effects (Brown et al. 2009, Fujita et al. 2009, Ma et al. 2009, Ford et al. 2011, Steinert et al. 2011). Recently, two studies aimed to investigate the role of sweeteners in gut 
barrier integrity. The authors demonstrated that artificial sweeteners disrupted gut barrier function by increasing intestinal permeability and apoptosis in vitro (Santos et al. 2018, Shil et al. 2020). Shil et al. proposed that sweettaste receptors were involved in this phenomenon since mice deleted for one of these receptors (T1R3) exhibited attenuated gut hyperpermeability (Shil et al. 2020). Given the presence of conflicting results regarding the effects of artificial sweeteners, additional studies on the topic have to be conducted to truly appreciate the safety of these additives.

\section{The effects of emulsifiers}

Another class of common additives is emulsifiers, which help to stabilize emulsions of liquids (such as mixes of oil and water). Emulsifiers are widely used, but some findings raise questions about their safety. In particular, carboxymethylcellulose (CMC) and polysorbate 80 (P80), two major emulsifiers, have been intensively studied for their capacity to trigger metabolic disorders. It has been demonstrated that CMC targets the microbial environment by promoting bacterial overgrowth in mice and that P80 enhances the translocation of $E$. coli in intestinal-derived M-cells (Swidsinski et al. 2009, Roberts et al. 2010). A few years later, Chassaing et al. showed that CMC and P80 exposure predisposed mice to low-grade inflammation and metabolic syndrome and enhanced susceptibility to colitis in $I l 10^{-/}$mice by a mechanism involving alteration of the mucus layer (Chassaing et al. 2015a). Indeed, they discovered that the use of specific emulsifiers changes the penetrability of the mucus by different bacteria, thereby increasing the close vicinity of microbial cells with intestinal epithelial cells. In this pioneering work, they demonstrated that the gut microbiota plays a major role since transferring the microbiota from emulsifier-treated mice to germ-free mice reproduced the alteration of the gut barrier with an altered mucus layer, increased disruption of TJPs and induced metabolic endotoxaemia (Chassaing et al. 2015a). Similarly, in the absence of the microbiota, the mice were protected against emulsifier-induced gut barrier dysfunction, low-grade inflammation and eventually the onset of metabolic disorders. These findings are strengthened by ex vivo studies showing that CMC and $\mathrm{p} 80$ exposure in a human gut microbiota simulator (M-SHIME) enhanced the pro-inflammatory potential by increasing the levels of bioactive flagellin through a mechanism involving the gut microbiota (Chassaing et al. 2017). Moreover, germfree mice receiving this altered gut microbiota recapitulated all the metabolic disorders listed above, thereby confirming the involvement of the gut microbiota in mediating the deleterious effects of emulsifiers on health. In addition to the potential implication of the gut microbiota, a recent study proposed that emulsifiers might alter food intake by modulating the expression of neuropeptides (i.e. increase in appetite-stimulating AgRP and decrease in appetitesuppressing $\alpha-\mathrm{MSH})$, thereby suggesting that emulsifiers may endanger health by modulating the gut-to-brain axis (Holder et al. 2019).

\section{The effect of fructose-rich diets}

The consumption of fructose soared across the world after the introduction of high-fructose corn syrup in the food industry in 1960. The overconsumption of fructose is strongly correlated with metabolic disorders, such as obesity, T2D, hepatic steatosis and cardiovascular diseases (Ouyang et al. 2008, Stanhope \& Havel 2009, Malik et al . 2010). At the intestinal level, fructose alters gut barrier integrity by several mechanisms. First, chronic fructose intake is associated with a drop in the levels of TJPs in the duodenum, especially occludin and Claudin-1 (Ritze et al . 2014, Zhou et al. 2014, Ochoa et al. 2015, Jegatheesan et al. 2016, Volynets et al. 2017). Because they observed an increase in serum endotoxin levels (i.e. metabolic endotoxaemia) and transcriptional activation of bacterial toll-like receptors, the authors proposed that fructose in combination with fat altered the gut barrier, leading to the translocation of bacterial products and thereby promoting hepatic inflammation (Spruss \& Bergheim 2009, Ochoa et al. 2015, Mazzotti et al. 2016). As observed with a highfat diet, fructose intake alters mucus integrity by reducing mucus thickness (Rahman et al. 2016, Volynets et al. 2017). Interestingly, Rahman et al showed that $\mathrm{F} 11 \mathrm{r}^{-/}$ mice exhibited all the features of NASH (hepatic steatosis with lobular inflammation and ballooning), in contrast to similarly fed WT mice, suggesting that disrupted gut barrier function is instrumental for the progression of hepatic steatosis to NASH (Rahman et al. 2016).

Because enteroendocrine cells express the fructose transporter GLUT5 (Reimann et al. 2008, Parker et al. 2009), it is assumed that they adapt to the production of gut hormones as a function of fructose concentrations. However, the effect of fructose on gut hormones is still under investigation. In humans, fructose is able to stimulate CCK, PYY and neutrotensin (NTS) in a manner similar to that of glucose and GLP-1 to a lesser extent. However, fructose has no effect on GIP kinetics in both humans and rodents, suggesting that fructose acts on GIP and GLP-1 in different ways (Kuhre et al. 2014). 


\section{Role of specific microbial metabolites in triggering metabolic diseases}

We have shown that modulation of the microbiota itself is sufficient to affect host metabolism. Via its contribution to the production of bioactive metabolites, such as organic compounds (e.g., nitric oxide (NO), carbon oxide, indole, ammonia, and hydrogen sulfide), branched-chain amino acids (BCAAs) and SCFAs and their derivatives, the gut microbiota is also able to use these channels to influence peripheral metabolism (Koh et al. 2016, Pedersen et al. 2016, Tomasova et al. 2016). As discussed in the chapter focused on prebiotics, most of the studies focused on the regulation of glucose tolerance and insulin signalling by SCFAs through a mechanism involving the endogenous production of GLP-1 and PYY.

However, the gut microbiota produces a multitude of metabolites, many of which enter the bloodstream and may have an impact on specific metabolic pathways as well. These include metabolites that are derived from the gut-driving metabolism of amino acids, and of these, trimethylamine (TMA) is the best documented. TMA is produced by the gut microbiota from dietary choline and carnitine and is converted into trimethylamineoxide (TMAO) by flavin-containing monooxygenase 3 (FMO3) in the liver. TMAO is strongly associated with the development of cardiovascular diseases and insulin resistance in humans (Wang et al. 2011, Bennett et al. 2013, Tang et al. 2013, Shih et al. 2015). Moreover, insulin-resistant mice lacking hepatic insulin receptor (LIRKO) exhibited an upregulation of $\mathrm{Fmo3}$ and subsequent increased levels of TMAO (Miao et al. 2015). Consistently, knockdown of Fmo3 in LIRKO mice prevented hyperglycaemia and atherosclerosis by suppressing FOXO1 protein expression and activity (Miao et al. 2015).

Another microbially produced amino acid-derived metabolite involved in the development of insulin resistance is imidazole propionate, which results from the histidine degradation pathway. Imidazole propionate is increased in individuals with type 2 diabetes (T2D) and impairs glucose tolerance and insulin signalling in HFDfed mice by a mechanism involving inhibition of insulin receptor substrate (IRS) through activation of the p38y/ p62/mTORC1 pathway (Koh et al. 2018).

Recently, the role of indolepropionic acid (IPA), a microbiota-produced deamination product of the amino acid tryptophan, has also been described. IPA is a bioactive compound that binds to pregnane $\mathrm{X}$ receptor (PXR) and aryl hydrocarbon receptor (Ahr) to exert effects on gut barrier integrity and glucose homeostasis (Zelante et al.
2013, Venkatesh et al. 2014, Hubbard et al. 2015, Agus et al. 2018). IPA has been described as inversely correlated with type 2 diabetes in humans (Tuomainen et al. 2018). In animals, data are controversial because IPA improved glucose metabolism and metabolic endotoxaemia in Sprague-Dawley rats (Abildgaard et al. 2018, Konopelski et al. 2019, Zhao et al. 2019), but its supplementation in mice fed a Western diet had no effect on glucose and lipid metabolism (Lee et al. 2020).

Taken together, these data on the different microbial metabolites illustrate their importance and pleiotropic roles in the functional capacity of the gut microbiota.

\section{General conclusions and perspectives}

Gut microbiota research has undoubtedly broadened our view on how metabolic pathways are regulated in an organism. However, despite the substantial technical progress made in the field, we still lack a real goldstandard analysis method. Most of the strategies rely on complementary approaches (i.e. taxonomic profiling, gene counts, and functional metagenomics), often in combination with metabolomics (i.e. analysis of the different metabolites produced by the microbiota). There is, however, a necessity for further technical advances, and many interrogations are still debated (Cani 2018). For example, while most of the studies use relative abundancies to evaluate microbial composition, the quantification of the absolute number of bacteria (i.e. cell counts or microbial load) may be an important aspect to take into account when exploring taxonomic changes. Jeroen Raes and his team have revealed new perspectives by showing that the relative quantification vs absolute quantification of gut bacteria could completely change the conclusions related to the association between specific bacteria and either health or diseases (Vandeputte et al. 2017). Their study strongly argues that most of the previous works using only relative proportions of microbes are possibly not capturing the entirety of a health situation. One striking example highlighted by the team is that the abundance of Bacteroides is connected with colitis (Crohn's disease) only after using relative abundance and not when using quantitative microbiota analysis (Vandeputte et al. 2017). Furthermore, these data emphasize the limitations of using relative abundance analysis since they can lead to specious interpretations.

Additionally, given the number of potential combinations of bacteria/metabolites and host genes/ susceptibilities, it is difficult to generalize all the findings 
discussed in this review. For example, Prevotella copri, which produces succinate, has been associated both positively and negatively with insulin resistance in two dietary approaches (Kovatcheva-Datchary et al. 2015, Pedersen et al. 2016). Therefore, the effects of specific microbial signatures and subsequently produced metabolites can differ drastically depending on the type of diet used (HFD or fibre-rich chow diet). The scientific community agrees on the fact that we have to progressively move towards personalized medicine, and it is likely that nutritional approaches will also need to be tailored to individual needs.

Finally, while there is little doubt about the existence of a causal link between gut microbes and energy homeostasis, further studies are still warranted, for example, to characterize the numerous interactions between microbes and different nutrients. Only then will it one day be possible to target the gut microbiota to address obesity and related disorders.

\section{Declaration of interest}

$P D C$ and $C K$ are co-founders of Enterosys S.A. (Labège, France). P D C is a co-founder of A-Mansia Biotech S.A. (Belgium) and owner of several patents concerning the use of microbiota and health.

\section{Funding}

P D C is a senior research associate at FRS-FNRS (Fonds de la Recherche Scientifique), Belgium. He is supported by the Fonds Baillet Latour (Grant for Medical Research 2015) and the Fonds de la Recherche Scientifique (FNRS, FRFS-WELBIO: WELBIO-CR-2019C-02R). C K is supported by a grant from the Agence Nationale de la Recherche (ANR) (ANR-18-CE14-0007-01).

\section{Author contribution statement}

All authors contributed equally to this work.

\section{References}

Abildgaard A, Elfving B, Hokland M, Wegener G \& Lund S 2018 The microbial metabolite indole-3-propionic acid improves glucose metabolism in rats, but does not affect behaviour. Archives of Physiology and Biochemistry 124 306-312. (https://doi.org/10.1080/138 13455.2017.1398262)

Abou-Donia MB, El-Masry EM, Abdel-Rahman AA, McLendon RE \& Schiffman SS 2008 Splenda alters gut microflora and increases intestinal p-glycoprotein and cytochrome p-450 in male rats. Journal of Toxicology and Environmental Health: Part A 71 1415-1429. (https:// doi.org/10.1080/15287390802328630)

Agus A, Planchais J \& Sokol H 2018 Gut microbiota regulation of tryptophan metabolism in health and disease. Cell Host and Microbe 23 716-724. (https://doi.org/10.1016/j.chom.2018.05.003)
Amar J, Burcelin R, Ruidavets JB, Cani PD, Fauvel J, Alessi MC, Chamontin B \& Ferrieres J 2008 Energy intake is associated with endotoxemia in apparently healthy men. American Journal of Clinical Nutrition 87 1219-1223. (https://doi.org/10.1093/ajcn/87.5.1219)

Anhe FF, Choi BSY, Dyck JRB, Schertzer JD \& Marette A 2019 Hostmicrobe interplay in the cardiometabolic benefits of dietary polyphenols. Trends in Endocrinology and Metabolism 30 384-395. (https://doi.org/10.1016/j.tem.2019.04.002)

Backhed F, Ding H, Wang T, Hooper LV, Koh GY, Nagy A, Semenkovich CF \& Gordon JI 2004 The gut microbiota as an environmental factor that regulates fat storage. PNAS 101 15718-15723. (https://doi org/10.1073/pnas.0407076101)

Backhed F, Manchester JK, Semenkovich CF \& Gordon JI 2007 Mechanisms underlying the resistance to diet-induced obesity in germ-free mice. PNAS 104 979-984. (https://doi.org/10.1073/pnas.0605374104)

Bennett BJ, de Aguiar Vallim TQ, Wang Z, Shih DM, Meng Y, Gregory J, Allayee H, Lee R, Graham M, Crooke R, et al. 2013 Trimethylamine-Noxide, a metabolite associated with atherosclerosis, exhibits complex genetic and dietary regulation. Cell Metabolism 17 49-60. (https://doi. org/10.1016/j.cmet.2012.12.011)

Bernardi S, Del Bo C, Marino M, Gargari G, Cherubini A, AndresLacueva C, Hidalgo-Liberona N, Peron G, Gonzalez-Dominguez R, Kroon P, et al. 2020 Polyphenols and intestinal permeability: rationale and future perspectives. Journal of Agricultural and Food Chemistry $\mathbf{6 8}$ 1816-1829. (https://doi.org/10.1021/acs.jafc.9b02283)

Bevins CL \& Salzman NH 2011 Paneth cells, antimicrobial peptides and maintenance of intestinal homeostasis. Nature Reviews: Microbiology 9 356-368. (https://doi.org/10.1038/nrmicro2546)

Boccellino M \& D'Angelo S 2020 Anti-obesity effects of polyphenol intake: current status and future possibilities. International Journal of Molecular Sciences 21 5642. (https://doi.org/10.3390/ijms21165642)

Boursier J, Mueller O, Barret M, Machado M, Fizanne L, Araujo-Perez F, Guy CD, Seed PC, Rawls JF, David LA, et al. 2016 The severity of nonalcoholic fatty liver disease is associated with gut dysbiosis and shift in the metabolic function of the gut microbiota. Hepatology $\mathbf{6 3}$ 764-775. (https://doi.org/10.1002/hep.28356)

Brooks L, Viardot A, Tsakmaki A, Stolarczyk E, Howard JK, Cani PD Everard A, Sleeth ML, Psichas A, Anastasovskaj J, et al. 2017 Fermentable carbohydrate stimulates FFAR2-dependent colonic PYY cell expansion to increase satiety. Molecular Metabolism 6 48-60. (https://doi.org/10.1016/j.molmet.2016.10.011)

Brown RJ, Walter M \& Rother KI 2009 Ingestion of diet soda before a glucose load augments glucagon-like peptide-1 secretion. Diabetes Care 32 2184-2186. (https://doi.org/10.2337/dc09-1185)

Buettner R, Schölmerich J \& Bollheimer LC 2007 High-fat diets: modeling the metabolic disorders of human obesity in rodents. Obesity $\mathbf{1 5}$ 798-808. (https://doi.org/10.1038/oby.2007.608)

Caesar R, Tremaroli V, Kovatcheva-Datchary P, Cani PD \& Bäckhed F 2015 Crosstalk between gut microbiota and dietary lipids aggravates WAT inflammation through TLR signaling. Cell Metabolism 22 658-668. (https://doi.org/10.1016/j.cmet.2015.07.026)

Cani PD 2017 Gut microbiota - at the intersection of everything? Nature Reviews: Gastroenterology and Hepatology 14 321-322. (https://doi. org/10.1038/nrgastro.2017.54)

Cani PD 2018 Human gut microbiome: hopes, threats and promises. Gut 67 1716-1725. (https://doi.org/10.1136/gutjnl-2018-316723)

Cani PD \& Delzenne NM 2009 The role of the gut microbiota in energy metabolism and metabolic disease. Current Pharmaceutical Design 15 1546-1558. (https://doi.org/10.2174/138161209788168164)

Cani PD \& Knauf C 2016 How gut microbes talk to organs: the role of endocrine and nervous routes. Molecular Metabolism 5 743-752. (https://doi.org/10.1016/j.molmet.2016.05.011)

Cani PD, Dewever C \& Delzenne NM 2004 Inulin-type fructans modulate gastrointestinal peptides involved in appetite regulation (glucagonlike peptide-1 and ghrelin) in rats. British Journal of Nutrition 92 521-526. (https://doi.org/10.1079/bjn20041225) https://joe.bioscientifica.com

https://doi.org/10.1530/JOE-20-0473
(C) 2021 Society for Endocrinology Published by Bioscientifica Ltd. Printed in Great Britain 
Cani PD, Knauf C, Iglesias MA, Drucker DJ, Delzenne NM \& Burcelin R 2006 Improvement of glucose tolerance and hepatic insulin sensitivity by oligofructose requires a functional glucagon-like peptide 1 receptor. Diabetes 55 1484-1490. (https://doi.org/10.2337/ db05-1360)

Cani PD, Neyrinck AM, Tuohy KM, Fava F, Gibson GR, Knauf C, Burcelin RG \& Delzenne NM 2007 Changes in gut microflora are responsible for high-fat diet-induced diabetes through a mechanism associated with endotoxaemia. Diabetologia 50 S68-S68. (https://doi. org/10.2337/db07-1403)

Cani PD, Bibiloni R, Knauf C, Waget A, Neyrinck AM, Delzenne NM \& Burcelin R 2008 Changes in gut microbiota control metabolic endotoxemia-induced inflammation in high-fat diet-induced obesity and diabetes in mice. Diabetes 57 1470-1481. (https://doi. org/10.2337/db07-1403)

Cani PD, Lecourt E, Dewulf EM, Sohet FM, Pachikian BD, Naslain D, De Backer F, Neyrinck AM \& Delzenne NM 2009a Gut microbiota fermentation of prebiotics increases satietogenic and incretin gut peptide production with consequences for appetite sensation and glucose response after a meal. American Journal of Clinical Nutrition 90 1236-1243. (https://doi.org/10.3945/ajcn.2009.28095)

Cani PD, Possemiers S, Van de Wiele T, Guiot Y, Everard A, Rottier O, Geurts L, Naslain D, Neyrinck AM, Lambert DM, et al. 2009b Changes in gut microbiota control inflammation in obese mice through a mechanism involving GLP-2-driven improvement of gut permeability. Gut 58 1091-1103. (https://doi.org/10.1136/gut.2008.165886)

Cani PD, Van Hul M, Lefort C, Depommier C, Rastelli M \& Everard A 2019 Microbial regulation of organismal energy homeostasis. Nature Metabolism 1 34-46. (https://doi.org/10.1038/s42255-018-0017-4)

Carocho M, Barreiro MF, Morales P \& Ferreira ICFR 2014 Adding molecules to food, pros and cons: a review on synthetic and natural food additives. Comprehensive Reviews in Food Science and Food Safety 13 377-399. (https://doi.org/10.1111/1541-4337.12065)

Chambers ES, Viardot A, Psichas A, Morrison DJ, Murphy KG, ZacVarghese SE, MacDougall K, Preston T, Tedford C, Finlayson GS, et al. 2015 Effects of targeted delivery of propionate to the human colon on appetite regulation, body weight maintenance and adiposity in overweight adults. Gut 64 1744-1754. (https://doi.org/10.1136/ gutjnl-2014-307913)

Chassaing B, Ley RE \& Gewirtz AT 2014 Intestinal epithelial cell toll-like receptor 5 regulates the intestinal microbiota to prevent low-grade inflammation and metabolic syndrome in mice. Gastroenterology $\mathbf{1 4 7}$ 1363.e17-1377.e17. (https://doi.org/10.1053/j.gastro.2014.08.033)

Chassaing B, Koren O, Goodrich JK, Poole AC, Srinivasan S, Ley RE \& Gewirtz AT 2015a Dietary emulsifiers impact the mouse gut microbiota promoting colitis and metabolic syndrome. Nature $\mathbf{5 1 9}$ 92-96. (https://doi.org/10.1038/nature14232)

Chassaing B, Miles-Brown J, Pellizzon M, Ulman E, Ricci M, Zhang L, Patterson AD, Vijay-Kumar M \& Gewirtz AT 2015b Lack of soluble fiber drives diet-induced adiposity in mice. American Journal of Physiology: Gastrointestinal and Liver Physiology 309 G528-G541. (https://doi.org/10.1152/ajpgi.00172.2015)

Chassaing B, Van de Wiele T, De Bodt J, Marzorati M \& Gewirtz AT 2017 Dietary emulsifiers directly alter human microbiota composition and gene expression ex vivo potentiating intestinal inflammation. Gut $\mathbf{6 6}$ 1414-1427. (https://doi.org/10.1136/gutjnl-2016-313099)

Cotillard A, Kennedy SP, Kong LC, Prifti E, Pons N, Le Chatelier E, Almeida M, Quinquis B, Levenez F, Galleron N, et al. 2013 Dietary intervention impact on gut microbial gene richness. Nature $\mathbf{5 0 0}$ 585-588. (https://doi.org/10.1038/nature12480)

Dalby MJ, Ross AW, Walker AW \& Morgan PJ 2017 Dietary uncoupling of gut microbiota and energy harvesting from obesity and glucose tolerance in mice. Cell Reports 21 1521-1533. (https://doi. org/10.1016/j.celrep.2017.10.056)

Delzenne NM, Cani PD, Daubioul C \& Neyrinck AM 2005 Impact of inulin and oligofructose on gastrointestinal peptides. British Journal of Nutrition 93 (Supplement 1) S157-S161. (https://doi.org/10.1079/ bjn20041342)

Delzenne NM, Neyrinck AM, Bäckhed F \& Cani PD 2011 Targeting gut microbiota in obesity: effects of prebiotics and probiotics. Nature Reviews: Endocrinology 7 639-646. (https://doi.org/10.1038/ nrendo.2011.126)

Denou E, Lolmede K, Garidou L, Pomie C, Chabo C, Lau TC, Fullerton MD, Nigro G, Zakaroff-Girard A, Luche E, et al. 2015 Defective NOD2 peptidoglycan sensing promotes diet-induced inflammation, dysbiosis, and insulin resistance. ЕМBO Molecular Medicine 7 259-274. (https://doi.org/10.15252/emmm.201404169)

Devkota S, Wang Y, Musch MW, Leone V, Fehlner-Peach H, Nadimpalli A, Antonopoulos DA, Jabri B \& Chang EB 2012 Dietary-fat-induced taurocholic acid promotes pathobiont expansion and colitis in Il10-/- mice. Nature 487 104-108. (https://doi.org/10.1038/ nature11225)

Dewulf EM, Cani PD, Claus SP, Fuentes S, Puylaert PG, Neyrinck AM, Bindels LB, de Vos WM, Gibson GR, Thissen JP, et al. 2013 Insight into the prebiotic concept: lessons from an exploratory, double blind intervention study with inulin-type fructans in obese women. Gut 62 1112-1121. (https://doi.org/10.1136/gutjnl-2012-303304)

Dray C, Knauf C, Daviaud D, Boucher J, Buleon M, Cani P, Attane C, Guigne C, Carpene C, Burcelin R, et al. 2007 Apelin stimulates glucose disposal in normal and insulino-resistant obese mice: emergence of a new insulin-sensitizing adipokine. International Journal of Obesity 31 1486-1486. (https://doi.org/10.1016/ j.cmet.2008.10.003)

Ehmann D, Wendler J, Koeninger L, Larsen IS, Klag T, Berger J, Marette A, Schaller M, Stange EF, Malek NP, et al. 2019 Paneth cell $\alpha$-defensins HD- 5 and HD- 6 display differential degradation into active antimicrobial fragments. PNAS 116 3746-3751. (https://doi. org/10.1073/pnas.1817376116)

Everard A, Lazarevic V, Derrien M, Girard M, Muccioli GG, Neyrinck AM, Possemiers S, Van Holle A, Francois P, de Vos WM, et al. 2011 Responses of gut microbiota and glucose and lipid metabolism to prebiotics in genetic obese and diet-induced leptin-resistant mice (vol 60, pg 2775, 2011). Diabetes 60 3307-3307. (https://doi.org/10.2337/ db11-er12c)

Everard A, Belzer C, Geurts L, Ouwerkerk JP, Druart C, Bindels LB, Guiot Y, Derrien M, Muccioli GG, Delzenne NM, et al. 2013 Cross-talk between Akkermansia muciniphila and intestinal epithelium controls diet-induced obesity. PNAS 110 9066-9071. (https://doi.org/10.1073/ pnas.1219451110)

Ford HE, Peters V, Martin NM, Sleeth ML, Ghatei MA, Frost GS \& Bloom SR 2011 Effects of oral ingestion of sucralose on gut hormone response and appetite in healthy normal-weight subjects. European Journal of Clinical Nutrition 65 508-513. (https://doi.org/10.1038/ ejcn.2010.291)

Frank DN, St Amand AL, Feldman RA, Boedeker EC, Harpaz N \& Pace NR 2007 Molecular-phylogenetic characterization of microbial community imbalances in human inflammatory bowel diseases. PNAS 104 13780-13785. (https://doi.org/10.1073/ pnas.0706625104)

Freeland KR \& Wolever TM 2010 Acute effects of intravenous and rectal acetate on glucagon-like peptide-1, peptide YY, ghrelin, adiponectin and tumour necrosis factor-alpha. British Journal of Nutrition $\mathbf{1 0 3}$ 460-466. (https://doi.org/10.1017/S0007114509991863)

Fujita Y, Wideman RD, Speck M, Asadi A, King DS, Webber TD, Haneda M \& Kieffer TJ 2009 Incretin release from gut is acutely enhanced by sugar but not by sweeteners in vivo. American Journal of Physiology: Endocrinology and Metabolism 296 E473-E479. (https://doi. org/10.1152/ajpendo.90636.2008)

Fujiyama Y, Hokari R, Miura S, Watanabe C, Komoto S, Oyama T, Kurihara C, Nagata H \& Hibi T 2007 Butter feeding enhances TNFalpha production from macrophages and lymphocyte adherence in murine small intestinal microvessels. Journal of Gastroenterology https://joe.bioscientifica.com

https://doi.org/10.1530/JOE-20-0473
(C) 2021 Society for Endocrinology Published by Bioscientifica Ltd. Printed in Great Britain 
and Hepatology 22 1838-1845. (https://doi.org/10.1111/j.14401746.2007.04905.x)

Geraedts MCP, Troost FJ \& Saris WHM 2011 Different tastants and lowcaloric sweeteners induce differential effects on the release of satiety hormones. Food Chemistry 129 731-738. (https://doi.org/10.1016/j. foodchem.2011.05.013)

Ghoshal S, Witta J, Zhong J, de Villiers W \& Eckhardt E 2009 Chylomicrons promote intestinal absorption of lipopolysaccharides. Journal of Lipid Research 50 90-97. (https://doi.org/10.1194/jlr M800156-JLR200)

Gibson GR, Hutkins R, Sanders ME, Prescott SL, Reimer RA, Salminen SJ, Scott K, Stanton C, Swanson KS, Cani PD, et al. 2017 Expert consensus document: the International Scientific Association for Probiotics and Prebiotics (ISAPP) consensus statement on the definition and scope of prebiotics. Nature Reviews: Gastroenterology and Hepatology 14 491-502. (https://doi.org/10.1038/nrgastro.2017.75)

Gomes JMG, Costa JA \& Alfenas RCG 2017 Metabolic endotoxemia and diabetes mellitus: a systematic review. Metabolism: Clinical and Experimental 68 133-144. (https://doi.org/10.1016/j. metabol.2016.12.009)

Gulhane M, Murray L, Lourie R, Tong H, Sheng YH, Wang R, Kang A, Schreiber V, Wong KY, Magor G, et al. 2016 High fat diets induce colonic epithelial cell stress and inflammation that is reversed by IL-22. Scientific Reports 6 28990. (https://doi.org/10.1038/srep28990)

Gummesson A, Carlsson LM, Storlien LH, Backhed F, Lundin P, Lofgren L, Stenlof K, Lam YY, Fagerberg B \& Carlsson B 2011 Intestinal permeability is associated with visceral adiposity in healthy women. Obesity 19 2280-2282. (https://doi.org/10.1038/oby.2011.251)

Hamilton MK, Boudry G, Lemay DG \& Raybould HE 2015 Changes in intestinal barrier function and gut microbiota in high-fat diet-fed rats are dynamic and region dependent. American Journal of Physiology: Gastrointestinal and Liver Physiology 308 G840-G851. (https://doi. org/10.1152/ajpgi.00029.2015)

Hiel S, Bindels LB, Pachikian BD, Kalala G, Broers V, Zamariola G, Chang BPI, Kambashi B, Rodriguez J, Cani PD, et al. 2019 Effects of a diet based on inulin-rich vegetables on gut health and nutritional behavior in healthy humans. American Journal of Clinical Nutrition 109 1683-1695. (https://doi.org/10.1093/ajcn/nqz001)

Holder MK, Peters NV, Whylings J, Fields CT, Gewirtz AT, Chassaing B \& de Vries GJ 2019 Dietary emulsifiers consumption alters anxiety-like and social-related behaviors in mice in a sex-dependent manner. Scientific Reports 9 172. (https://doi.org/10.1038/s41598-018-36890-3)

Holmes E, Li JV, Athanasiou T, Ashrafian H \& Nicholson JK 2011 Understanding the role of gut microbiome-host metabolic signal disruption in health and disease. Trends in Microbiology 19 349-359. (https://doi.org/10.1016/j.tim.2011.05.006)

Hooper LV \& Macpherson AJ 2010 Immune adaptations that maintain homeostasis with the intestinal microbiota. Nature Reviews: Immunology 10 159-169. (https://doi.org/10.1038/nri2710)

Horton F, Wright J, Smith L, Hinton PJ \& Robertson MD 2014 Increased intestinal permeability to oral chromium (51 Cr)-EDTA in human Type 2 diabetes. Diabetic Medicine 31 559-563. (https://doi. org/10.1111/dme.12360)

Hubbard TD, Murray IA \& Perdew GH 2015 Indole and tryptophan metabolism: endogenous and dietary routes to ah receptor activation. Drug Metabolism and Disposition 43 1522-1535. (https://doi. org/10.1124/dmd.115.064246)

Jang HJ, Kokrashvili Z, Theodorakis MJ, Carlson OD, Kim BJ, Zhou J, Kim HH, Xu X, Chan SL, Juhaszova M, et al. 2007 Gut-expressed gustducin and taste receptors regulate secretion of glucagon-like peptide-1. PNAS 104 15069-15074. (https://doi.org/10.1073/ pnas.0706890104)

Jayashree B, Bibin YS, Prabhu D, Shanthirani CS, Gokulakrishnan K, Lakshmi BS, Mohan V \& Balasubramanyam M 2014 Increased circulatory levels of lipopolysaccharide (LPS) and zonulin signify novel biomarkers of proinflammation in patients with type 2 diabetes. Molecular and Cellular Biochemistry 388 203-210. (https:// doi.org/10.1007/s11010-013-1911-4)

Jegatheesan P, Beutheu S, Freese K, Waligora-Dupriet AJ, Nubret E, Butel MJ, Bergheim I \& De Bandt JP 2016 Preventive effects of citrulline on Western diet-induced non-alcoholic fatty liver disease in rats. British Journal of Nutrition 116 191-203. (https://doi.org/10.1017/ S0007114516001793)

Jensen BA, Nielsen TS, Fritzen AM, Holm JB, Fjære E, Serup AK, Borkowski K, Risis S, Pærregaard SI, Søgaard I, et al. 2016 Dietary fat drives whole-body insulin resistance and promotes intestinal inflammation independent of body weight gain. Metabolism: Clinical and Experimental 65 1706-1719. (https://doi.org/10.1016/j. metabol.2016.09.002)

Johansson ME, Gustafsson JK, Holmén-Larsson J, Jabbar KS, Xia L, Xu H, Ghishan FK, Carvalho FA, Gewirtz AT, Sjövall H, et al. 2014 Bacteria penetrate the normally impenetrable inner colon mucus layer in both murine colitis models and patients with ulcerative colitis. Gut $\mathbf{6 3}$ 281-291. (https://doi.org/10.1136/gutjnl-2012-303207)

Just S, Mondot S, Ecker J, Wegner K, Rath E, Gau L, Streidl T, HeryArnaud G, Schmidt S, Lesker TR, et al. 2018 The gut microbiota drives the impact of bile acids and fat source in diet on mouse metabolism. Microbiome 6 134. (https://doi.org/10.1186/s40168-0180510-8)

Karlsson FH, Tremaroli V, Nookaew I, Bergström G, Behre CJ, Fagerberg B, Nielsen J \& Bäckhed F 2013 Gut metagenome in European women with normal, impaired and diabetic glucose control. Nature $\mathbf{4 9 8}$ 99-103. (https://doi.org/10.1038/nature12198)

Kawano Y, Nakae J, Watanabe N, Kikuchi T, Tateya S, Tamori Y, Kaneko M, Abe T, Onodera M \& Itoh H 2016 Colonic proinflammatory macrophages cause insulin resistance in an intestinal Ccl2/Ccr2-dependent manner. Cell Metabolism 24 295-310. (https:// doi.org/10.1016/j.cmet.2016.07.009)

Kidd M, Modlin IM, Gustafsson BI, Drozdov I, Hauso O \& Pfragner R 2008 Luminal regulation of normal and neoplastic human EC cell serotonin release is mediated by bile salts, amines, tastants, and olfactants. American Journal of Physiology: Gastrointestinal and Liver Physiology 295 G260-G272. (https://doi.org/10.1152/ ajpgi.00056.2008)

Koh A, De Vadder F, Kovatcheva-Datchary P \& Bäckhed F 2016 From dietary fiber to host physiology: short-chain fatty acids as key bacterial metabolites. Cell 165 1332-1345. (https://doi.org/10.1016/j. cell.2016.05.041)

Koh A, Molinaro A, Ståhlman M, Khan MT, Schmidt C, ManneråsHolm L, Wu H, Carreras A, Jeong H, Olofsson LE, et al. 2018 Microbially produced imidazole propionate impairs insulin signaling through mTORC1. Cell 175 947.e17-961.e17. (https://doi. org/10.1016/j.cell.2018.09.055)

Konig J, Wells J, Cani PD, Garcia-Rodenas CL, MacDonald T, Mercenier A, Whyte J, Troost F \& Brummer RJ 2016 Human intestinal barrier function in health and disease. Clinical and Translational Gastroenterology 7 e196. (https://doi.org/10.1038/ctg.2016.54)

Konopelski P, Konop M, Gawrys-Kopczynska M, Podsadni P, Szczepanska A \& Ufnal M 2019 Indole-3-propionic acid, a tryptophan-derived bacterial metabolite, reduces weight gain in rats. Nutrients 11 591. (https://doi.org/10.3390/nu11030591)

Kootte RS, Levin E, Salojärvi J, Smits LP, Hartstra AV, Udayappan SD, Hermes G, Bouter KE, Koopen AM, Holst JJ, et al. 2017 Improvement of insulin sensitivity after lean donor feces in metabolic syndrome is driven by baseline intestinal microbiota composition. Cell Metabolism 26 611.e6-619.e6. (https://doi.org/10.1016/j.cmet.2017.09.008)

Korczak R \& Slavin JL 2018 Fructooligosaccharides and appetite. Current Opinion in Clinical Nutrition and Metabolic Care 21 377-380. (https:// doi.org/10.1097/MCO.0000000000000502)

Kovatcheva-Datchary P, Nilsson A, Akrami R, Lee YS, De Vadder F, Arora T, Hallen A, Martens E, Björck I \& Bäckhed F 2015 Dietary fiber-induced improvement in glucose metabolism is associated with https://joe.bioscientifica.com

https://doi.org/10.1530/JOE-20-0473 (c) 2021 Society for Endocrinology Published by Bioscientifica Ltd. Printed in Great Britain 
increased abundance of Prevotella. Cell Metabolism 22 971-982. (https://doi.org/10.1016/j.cmet.2015.10.001)

Kuhre RE, Gribble FM, Hartmann B, Reimann F, Windeløv JA, Rehfeld JF \& Holst JJ 2014 Fructose stimulates GLP-1 but not GIP secretion in mice, rats, and humans. American Journal of Physiology: Gastrointestinal and Liver Physiology 306 G622-G630. (https://doi.org/10.1152/ ajpgi.00372.2013)

Lam YY, Ha CW, Hoffmann JM, Oscarsson J, Dinudom A, Mather TJ, Cook DI, Hunt NH, Caterson ID, Holmes AJ, et al. 2015 Effects of dietary fat profile on gut permeability and microbiota and their relationships with metabolic changes in mice. Obesity 23 1429-1439. (https://doi.org/10.1002/oby.21122)

Lassenius MI, Pietilainen KH, Kaartinen K, Pussinen PJ, Syrjanen J, Forsblom C, Porsti I, Rissanen A, Kaprio J, Mustonen J, et al. 2011 Bacterial endotoxin activity in human serum is associated with dyslipidemia, insulin resistance, obesity, and chronic inflammation. Diabetes Care 34 1809-1815. (https://doi.org/10.2337/dc10-2197)

Laugerette F, Vors C, Geloen A, Chauvin MA, Soulage C, LambertPorcheron S, Peretti N, Alligier M, Burcelin R, Laville M, et al. 2011 Emulsified lipids increase endotoxemia: possible role in early postprandial low-grade inflammation. Journal of Nutritional Biochemistry 22 53-59. (https://doi.org/10.1016/j. jnutbio.2009.11.011)

Le Chatelier E, Nielsen T, Qin J, Prifti E, Hildebrand F, Falony G, Almeida M, Arumugam M, Batto JM, Kennedy S, et al. 2013 Richness of human gut microbiome correlates with metabolic markers. Nature 500 541-546. (https://doi.org/10.1038/nature12506)

Le Poul E, Loison C, Struyf S, Springael JY, Lannoy V, Decobecq ME, Brezillon S, Dupriez V, Vassart G, Van Damme J, et al. 2003 Functional characterization of human receptors for short chain fatty acids and their role in polymorphonuclear cell activation. Journal of Biological Chemistry 278 25481-25489. (https://doi.org/10.1074/jbc. M301403200)

Le Roy T, Llopis M, Lepage P, Bruneau A, Rabot S, Bevilacqua C, Martin P, Philippe C, Walker F, Bado A, et al. 2013 Intestinal microbiota determines development of non-alcoholic fatty liver disease in mice. Gut 62 1787-1794. (https://doi.org/10.1136/gutjnl-2012-303816)

Lee DM, Ecton KE, Trikha SRJ, Wrigley SD, Thomas KN, Battson ML, Wei Y, Johnson SA, Weir TL \& Gentile CL 2020 Microbial metabolite indole-3-propionic acid supplementation does not protect mice from the cardiometabolic consequences of a Western diet. American Journal of Physiology: Gastrointestinal and Liver Physiology 319 G51-G62. (https://doi.org/10.1152/ajpgi.00375.2019)

Luck H, Tsai S, Chung J, Clemente-Casares X, Ghazarian M, Revelo XS, Lei H, Luk CT, Shi SY, Surendra A, et al. 2015 Regulation of obesityrelated insulin resistance with gut anti-inflammatory agents. Cell Metabolism 21 527-542. (https://doi.org/10.1016/j.cmet.2015.03.001)

Lupp C, Robertson ML, Wickham ME, Sekirov I, Champion OL, Gaynor EC \& Finlay BB 2007 Host-mediated inflammation disrupts the intestinal microbiota and promotes the overgrowth of Enterobacteriaceae. Cell Host and Microbe 2 119-129. (https://doi. org/10.1016/j.chom.2007.06.010)

Lynch SV \& Pedersen O 2016 The human intestinal microbiome in health and disease. New England Journal of Medicine 375 2369-2379. (https://doi.org/10.1056/NEJMra1600266)

Ma J, Bellon M, Wishart JM, Young R, Blackshaw LA, Jones KL, Horowitz M \& Rayner CK 2009 Effect of the artificial sweetener, sucralose, on gastric emptying and incretin hormone release in healthy subjects. American Journal of Physiology: Gastrointestinal and Liver Physiology 296 G735-G739. (https://doi.org/10.1152/ ajpgi.90708.2008)

Macpherson AJ \& Harris NL 2004 Interactions between commensal intestinal bacteria and the immune system. Nature Reviews: Immunology 4 478-485. (https://doi.org/10.1038/nri1373)

Macpherson AJ, Geuking MB, Slack E, Hapfelmeier S \& McCoy KD 2012 The habitat, double life, citizenship, and forgetfulness of IgA.
Immunological Reviews 245 132-146. (https://doi.org/10.1111/j.1600065X.2011.01072.x)

Makki K, Deehan EC, Walter J \& Bäckhed F 2018 The impact of dietary fiber on gut microbiota in host health and disease. Cell Host and Microbe 23 705-715. (https://doi.org/10.1016/j. chom.2018.05.012)

Malik VS, Popkin BM, Bray GA, Després JP \& Hu FB 2010 Sugar-sweetened beverages, obesity, type 2 diabetes mellitus, and cardiovascular disease risk. Circulation 121 1356-1364. (https://doi.org/10.1161/ CIRCULATIONAHA.109.876185)

Margolskee RF, Dyer J, Kokrashvili Z, Salmon KS, Ilegems E, Daly K, Maillet EL, Ninomiya Y, Mosinger B \& Shirazi-Beechey SP 2007 T1R3 and gustducin in gut sense sugars to regulate expression of Na+-glucose cotransporter 1. PNAS 104 15075-15080. (https://doi. org/10.1073/pnas.0706678104)

Mazzotti A, Caletti MT, Sasdelli AS, Brodosi L \& Marchesini G 2016 Pathophysiology of nonalcoholic fatty liver disease: lifestyle-gut-gene interaction. Digestive Diseases 34 (Supplement 1) 3-10. (https://doi. org/10.1159/000447275)

Miao J, Ling AV, Manthena PV, Gearing ME, Graham MJ, Crooke RM, Croce KJ, Esquejo RM, Clish CB, Morbid Obesity Study Group, et al. 2015 Flavin-containing monooxygenase 3 as a potential player in diabetes-associated atherosclerosis. Nature Communications 66498 (https://doi.org/10.1038/ncomms7498)

Michail S, Lin M, Frey MR, Fanter R, Paliy O, Hilbush B \& Reo NV 2015 Altered gut microbial energy and metabolism in children with non-alcoholic fatty liver disease. FEMS Microbiology Ecology 91 1-9. (https://doi.org/10.1093/femsec/fiu002)

Miles JP, Zou J, Kumar MV, Pellizzon M, Ulman E, Ricci M, Gewirtz AT \& Chassaing B 2017 Supplementation of low- and high-fat diets with fermentable fiber exacerbates severity of DSS-induced acute colitis. Inflammatory Bowel Diseases 23 1133-1143. (https://doi.org/10.1097/ MIB.0000000000001155)

Monte SV, Caruana JA, Ghanim H, Sia CL, Korzeniewski K, Schentag JJ \& Dandona P 2012 Reduction in endotoxemia, oxidative and inflammatory stress, and insulin resistance after Roux-en-Y gastric bypass surgery in patients with morbid obesity and type 2 diabetes mellitus. Surgery 151 587-593. (https://doi.org/10.1016/j. surg.2011.09.038)

Ochoa M, Lallès JP, Malbert CH \& Val-Laillet D 2015 Dietary sugars: their detection by the gut-brain axis and their peripheral and central effects in health and diseases. European Journal of Nutrition 54 1-24. (https:// doi.org/10.1007/s00394-014-0776-y)

Ouyang X, Cirillo P, Sautin Y, McCall S, Bruchette JL, Diehl AM, Johnson RJ \& Abdelmalek MF 2008 Fructose consumption as a risk factor for non-alcoholic fatty liver disease. Journal of Hepatology 48 993-999. (https://doi.org/10.1016/j.jhep.2008.02.011)

Pal D, Dasgupta S, Kundu R, Maitra S, Das G, Mukhopadhyay S, Ray S, Majumdar SS \& Bhattacharya S 2012 Fetuin-A acts as an endogenous ligand of TLR4 to promote lipid-induced insulin resistance. Nature Medicine 18 1279-1285. (https://doi.org/ $10.1038 / \mathrm{nm} .2851)$

Paone P \& Cani PD 2020 Mucus barrier, mucins and gut microbiota: the expected slimy partners? Gut 69 2232-2243. (https://doi.org/10.1136/ gutjnl-2020-322260)

Parker HE, Habib AM, Rogers GJ, Gribble FM \& Reimann F 2009 Nutrientdependent secretion of glucose-dependent insulinotropic polypeptide from primary murine K cells. Diabetologia 52 289-298. (https://doi. org/10.1007/s00125-008-1202-x)

Parnell JA \& Reimer RA 2009 Weight loss during oligofructose supplementation is associated with decreased ghrelin and increased peptide YY in overweight and obese adults. American Journal of Clinical Nutrition 89 1751-1759. (https://doi.org/10.3945/ajcn.2009.27465)

Pedersen HK, Gudmundsdottir V, Nielsen HB, Hyotylainen T, Nielsen T, Jensen BA, Forslund K, Hildebrand F, Prifti E, Falony G, et al. 2016 Human gut microbes impact host serum metabolome and https://joe.bioscientifica.com

https://doi.org/10.1530/JOE-20-0473 (c) 2021 Society for Endocrinology Published by Bioscientifica Ltd. Printed in Great Britain 
insulin sensitivity. Nature 535 376-381. (https://doi.org/10.1038/ nature18646)

Pellizzon MA \& Ricci MR 2018 The common use of improper control diets in diet-induced metabolic disease research confounds data interpretation: the fiber factor. Nutrition and Metabolism 15 3. (https:// doi.org/10.1186/s12986-018-0243-5)

Pierre JF, Heneghan AF, Feliciano RP, Shanmuganayagam D, Roenneburg DA, Krueger CG, Reed JD \& Kudsk KA 2013 Cranberry proanthocyanidins improve the gut mucous layer morphology and function in mice receiving elemental enteral nutrition. Journal of Parenteral and Enteral Nutrition 37 401-409. (https://doi. org/10.1177/0148607112463076)

Pott J \& Hornef M 2012 Innate immune signalling at the intestinal epithelium in homeostasis and disease. EMBO Reports 13 684-698. (https://doi.org/10.1038/embor.2012.96)

Pussinen PJ, Havulinna AS, Lehto M, Sundvall J \& Salomaa V 2011 Endotoxemia is associated with an increased risk of incident diabetes. Diabetes Care 34 392-397. (https://doi.org/10.2337/ dc10-1676)

Radilla-Vazquez RB, Parra-Rojas I, Martinez-Hernandez NE, MarquezSandoval YF, Illades-Aguiar B \& Castro-Alarcon N 2016 Gut microbiota and metabolic endotoxemia in young obese Mexican subjects. Obesity Facts 9 1-11. (https://doi.org/10.1159/000442479)

Rahman K, Desai C, Iyer SS, Thorn NE, Kumar P, Liu Y, Smith T, Neish AS, Li H, Tan S, et al. 2016 Loss of junctional adhesion molecule A promotes severe steatohepatitis in mice on a diet high in saturated fat, fructose, and cholesterol. Gastroenterology 151 733.e12-746.e12. (https://doi.org/10.1053/j.gastro.2016. 06.022)

Raimondi F, Santoro P, Barone MV, Pappacoda S, Barretta ML, Nanayakkara M, Apicella C, Capasso L \& Paludetto R 2008 Bile acids modulate tight junction structure and barrier function of Caco-2 monolayers via EGFR activation. American Journal of Physiology: Gastrointestinal and Liver Physiology 294 G906-G913. (https://doi. org/10.1152/ajpgi.00043.2007)

Rao M, Gao C, Xu L, Jiang L, Zhu J, Chen G, Law BYK \& Xu Y 2019 Effect of inulin-type carbohydrates on insulin resistance in patients with Type 2 diabetes and obesity: a systematic review and metaanalysis. Journal of Diabetes Research 2019 5101423. (https://doi. org/10.1155/2019/5101423)

Rastelli M, Knauf C \& Cani PD 2018 Gut microbes and health: a focus on the mechanisms linking microbes, obesity, and related disorders. Obesity 26 792-800. (https://doi.org/10.1002/oby.22175)

Rastelli M, Cani PD \& Knauf C 2019 The gut microbiome influences hos endocrine functions. Endocrine Reviews 40 1271-1284. (https://doi. org/10.1210/er.2018-00280)

Reid G, Gadir AA \& Dhir R 2019 Probiotics: reiterating what they are and what they are not. Frontiers in Microbiology 10 424. (https://doi. org/10.3389/fmicb.2019.00424)

Reimann F, Habib AM, Tolhurst G, Parker HE, Rogers GJ \& Gribble FM 2008 Glucose sensing in L cells: a primary cell study. Cell Metabolism 8 532-539. (https://doi.org/10.1016/j.cmet.2008.11.002)

Ritze Y, Bárdos G, Claus A, Ehrmann V, Bergheim I, Schwiertz A \& Bischoff SC 2014 Lactobacillus rhamnosus GG protects against nonalcoholic fatty liver disease in mice. PLOS ONE 9 e80169. (https://doi. org/10.1371/journal.pone.0080169)

Roberfroid M, Gibson GR, Hoyles L, McCartney AL, Rastall R, Rowland I, Wolvers D, Watzl B, Szajewska H, Stahl B, et al. 2010 Prebiotic effects: metabolic and health benefits. British Journal of Nutrition 104 (Supplement 2) S1-S63. (https://doi.org/10.1017/ S0007114510003363)

Roberts CL, Keita AV, Duncan SH, O'Kennedy N, Söderholm JD, Rhodes JM \& Campbell BJ 2010 Translocation of Crohn's disease Escherichia coli across M-cells: contrasting effects of soluble plant fibres and emulsifiers. Gut 59 1331-1339. (https://doi.org/10.1136/ gut.2009.195370)
Rodriguez J, Hiel S, Neyrinck AM, Le Roy T, Potgens SA, Leyrolle Q, Pachikian BD, Gianfrancesco MA, Cani PD, Paquot N, et al. 2020 Discovery of the gut microbial signature driving the efficacy of prebiotic intervention in obese patients. Gut 69 1975-1987. (https:// doi.org/10.1136/gutjnl-2019-319726)

Rodríguez-Daza MC, Daoust L, Boutkrabt L, Pilon G, Varin T, Dudonné S, Levy É, Marette A, Roy D \& Desjardins Y 2020 Wild blueberry proanthocyanidins shape distinct gut microbiota profile and influence glucose homeostasis and intestinal phenotypes in highfat high-sucrose fed mice. Scientific Reports 10 2217. (https://doi. org/10.1038/s41598-020-58863-1)

Salzman NH, Hung K, Haribhai D, Chu H, Karlsson-Sjöberg J, Amir E, Teggatz P, Barman M, Hayward M, Eastwood D, et al. 2010 Enteric defensins are essential regulators of intestinal microbial ecology. Nature Immunology 11 76-83. (https://doi.org/10.1038/ni.1825)

Sanders ME, Merenstein DJ, Reid G, Gibson GR \& Rastall RA 2019 Probiotics and prebiotics in intestinal health and disease: from biology to the clinic. Nature Reviews: Gastroenterology and Hepatology 16 605-616. (https://doi.org/10.1038/s41575-019-0173-3)

Santos PS, Caria CRP, Gotardo EMF, Ribeiro ML, Pedrazzoli J \& Gambero A 2018 Artificial sweetener saccharin disrupts intestinal epithelial cells' barrier function in vitro. Food and Function 9 3815-3822. (https://doi.org/10.1039/c8fo00883c)

Shih DM, Wang Z, Lee R, Meng Y, Che N, Charugundla S, Qi H, Wu J, Pan C, Brown JM, et al. 2015 Flavin containing monooxygenase 3 exerts broad effects on glucose and lipid metabolism and atherosclerosis. Journal of Lipid Research 56 22-37. (https://doi. org/10.1194/jlr.M051680)

Shil A, Olusanya O, Ghufoor Z, Forson B, Marks J \& Chichger H 2020 Artificial sweeteners disrupt tight junctions and barrier function in the intestinal epithelium through activation of the sweet taste receptor, T1R3. Nutrients 12 1862. (https://doi.org/10.3390/ nu12061862)

Singh V, Yeoh BS, Chassaing B, Xiao X, Saha P, Aguilera Olvera R, Lapek JD, Jr, Zhang L, Wang WB, Hao S, et al. 2018 Dysregulated microbial fermentation of soluble fiber induces cholestatic liver. Cancer: Cell 175 679.e622-694.e622. (https://doi.org/10.1016/ j.cell.2018.09.004)

Sookoian S, Salatino A, Castaño GO, Landa MS, Fijalkowky C, Garaycoechea M \& Pirola CJ 2020 Intrahepatic bacterial metataxonomic signature in non-alcoholic fatty liver disease. Gut 69 1483-1491. (https://doi.org/10.1136/gutjnl-2019-318811)

Spruss A \& Bergheim I 2009 Dietary fructose and intestinal barrier: potential risk factor in the pathogenesis of nonalcoholic fatty liver disease. Journal of Nutritional Biochemistry 20 657-662. (https://doi. org/10.1016/j.jnutbio.2009.05.006)

Stange EF \& Schroeder BO 2019 Microbiota and mucosal defense in IBD: an update. Expert Review of Gastroenterology and Hepatology $\mathbf{1 3}$ 963-976. (https://doi.org/10.1080/17474124.2019.1671822)

Stanhope KL \& Havel PJ 2009 Fructose consumption: considerations for future research on its effects on adipose distribution, lipid metabolism, and insulin sensitivity in humans. Journal of Nutrition 139 1236S-1241S. (https://doi.org/10.3945/jn.109.106641)

Steinert RE, Frey F, Töpfer A, Drewe J \& Beglinger C 2011 Effects of carbohydrate sugars and artificial sweeteners on appetite and the secretion of gastrointestinal satiety peptides. British Journal of Nutrition 105 1320-1328. (https://doi.org/10.1017/ S000711451000512X)

Stenman LK, Holma R \& Korpela R 2012 High-fat-induced intestinal permeability dysfunction associated with altered fecal bile acids. World Journal of Gastroenterology 18 923-929. (https://doi.org/10.3748/ wjg.v18.i9.923)

Suez J, Korem T, Zeevi D, Zilberman-Schapira G, Thaiss CA, Maza O, Israeli D, Zmora N, Gilad S, Weinberger A, et al. 2014 Artificial sweeteners induce glucose intolerance by altering the gut microbiota. Nature 514 181-186. (https://doi.org/10.1038/nature13793) https://joe.bioscientifica.com

https://doi.org/10.1530/JOE-20-0473 (c) 2021 Society for Endocrinology Published by Bioscientifica Ltd. Printed in Great Britain 
Suzuki T \& Hara H 2010 Dietary fat and bile juice, but not obesity, are responsible for the increase in small intestinal permeability induced through the suppression of tight junction protein expression in LETO and OLETF rats. Nutrition and Metabolism 7 19. (https://doi. org/10.1186/1743-7075-7-19)

Swidsinski A, Ung V, Sydora BC, Loening-Baucke V, Doerffel Y, Verstraelen H \& Fedorak RN 2009 Bacterial overgrowth and inflammation of small intestine after carboxymethylcellulose ingestion in genetically susceptible mice. Inflammatory Bowel Diseases 15 359-364. (https://doi.org/10.1002/ibd.20763)

Tang WH, Wang Z, Levison BS, Koeth RA, Britt EB, Fu X, Wu Y \& Hazen SL 2013 Intestinal microbial metabolism of phosphatidylcholine and cardiovascular risk. New England Journal of Medicine 368 1575-1584. (https://doi.org/10.1056/NEJMoa1109400)

Teng H \& Chen L 2019 Polyphenols and bioavailability: an update. Critical Reviews in Food Science and Nutrition 59 2040-2051. (https:// doi.org/10.1080/10408398.2018.1437023)

Tomasova L, Konopelski P \& Ufnal M 2016 Gut bacteria and hydrogen sulfide: the new old players in circulatory system homeostasis. Molecules 21 1558. (https://doi.org/10.3390/molecules21111558)

Tuomainen M, Lindstrom J, Lehtonen M, Auriola S, Pihlajamaki J, Peltonen M, Tuomilehto J, Uusitupa M, de Mello VD \& Hanhineva K 2018 Associations of serum indolepropionic acid, a gut microbiota metabolite, with type 2 diabetes and low-grade inflammation in highrisk individuals. Nutrition and Diabetes 8 35. (https://doi.org/10.1038/ s41387-018-0046-9)

Van Hul M, Geurts L, Plovier H, Druart C, Everard A, Stahlman M, Rhimi M, Chira K, Teissedre PL, Delzenne NM, et al. 2018 Reduced obesity, diabetes and steatosis upon cinnamon and grape pomace are associated with changes in gut microbiota and markers of gut barrier. American Journal of Physiology: Endocrinology and Metabolism 314 E334-E352. (https://doi.org/10.1152/ ajpendo.00107.2017)

Van Hul M, Karnik K, Canene-Adams K, De Souza M, Van den Abbeele P, Marzorati M, Delzenne NM, Everard A \& Cani PD 2020 Comparison of the effects of soluble corn fiber and fructooligosaccharides on metabolism, inflammation and gut microbiome of high-fat diet fed mice. American Journal of Physiology: Endocrinology and Metabolism 319 E779-E791. (https:// doi.org/10.1152/ajpendo.00108.2020)

Vandeputte D, Kathagen G, D'Hoe K, Vieira-Silva S, Valles-Colomer M, Sabino J, Wang J, Tito RY, De Commer L, Darzi Y, et al. 2017 Quantitative microbiome profiling links gut community variation to microbial load. Nature $\mathbf{5 5 1}$ 507-511. (https://doi.org/10.1038/ nature24460)

Venkatesh M, Mukherjee S, Wang H, Li H, Sun K, Benechet AP, Qiu Z, Maher L, Redinbo MR, Phillips RS, et al. 2014 Symbiotic bacterial metabolites regulate gastrointestinal barrier function via the xenobiotic sensor PXR and toll-like receptor 4. Immunity 41 296-310. (https://doi.org/10.1016/j.immuni.2014.06.014)

Vijay-Kumar M, Aitken JD, Carvalho FA, Cullender TC, Mwangi S, Srinivasan S, Sitaraman SV, Knight R, Ley RE \& Gewirtz AT 2010 Metabolic syndrome and altered gut microbiota in mice lacking Toll-like receptor 5. Science 328 228-231. (https://doi.org/10.1126/ science.1179721)

Volynets V, Louis S, Pretz D, Lang L, Ostaff MJ, Wehkamp J \& Bischoff SC 2017 Intestinal barrier function and the gut microbiome are differentially affected in mice fed a western-style diet or drinking water supplemented with fructose. Journal of Nutrition 147 770-780. (https://doi.org/10.3945/jn.116.242859)

Voth DE \& Ballard JD 2005 Clostridium difficile toxins: mechanism of action and role in disease. Clinical Microbiology Reviews 18 247-263. (https://doi.org/10.1128/CMR.18.2.247-263.2005)

Vrieze A, Van Nood E, Holleman F, Salojärvi J, Kootte RS, Bartelsman JF, Dallinga-Thie GM, Ackermans MT, Serlie MJ,
Oozeer R, et al. 2012 Transfer of intestinal microbiota from lean donors increases insulin sensitivity in individuals with metabolic syndrome. Gastroenterology 143 913.e7-916.e7. (https://doi. org/10.1053/j.gastro.2012.06.031)

Wang Z, Klipfell E, Bennett BJ, Koeth R, Levison BS, Dugar B, Feldstein AE, Britt EB, Fu X, Chung YM, et al. 2011 Gut flora metabolism of phosphatidylcholine promotes cardiovascular disease. Nature 472 57-63. (https://doi.org/10.1038/nature09922)

Wang B, Jiang X, Cao M, Ge J, Bao Q, Tang L, Chen Y \& Li L 2016 Altered fecal microbiota correlates with liver biochemistry in nonobese patients with non-alcoholic fatty liver disease. Scientific Reports 6 32002. (https://doi.org/10.1038/srep32002)

Wehkamp J, Koslowski M, Wang G \& Stange EF 2008 Barrier dysfunction due to distinct defensin deficiencies in small intestinal and colonic Crohn's disease. Mucosal Immunology 1 (Supplement 1) S67-S74. (https://doi.org/10.1038/mi.2008.48)

Wei X, Yang Z, Rey FE, Ridaura VK, Davidson NO, Gordon JI \& Semenkovich CF 2012 Fatty acid synthase modulates intestinal barrier function through palmitoylation of mucin 2. Cell Host and Microbe 11 140-152. (https://doi.org/10.1016/j.chom. 2011.12.006)

Wells JM, Brummer RJ, Derrien M, MacDonald TT, Troost F, Cani PD, Theodorou V, Dekker J, Meheust A, de Vos WM, et al. 2017 Homeostasis of the gut barrier and potential biomarkers. American Journal of Physiology: Gastrointestinal and Liver Physiology $\mathbf{3 1 2}$ G171-G193. (https://doi.org/10.1152/ajpgi.00048.2015)

Wikoff WR, Anfora AT, Liu J, Schultz PG, Lesley SA, Peters EC \& Siuzdak G 2009 Metabolomics analysis reveals large effects of gut microflora on mammalian blood metabolites. PNAS 106 3698-3703. (https://doi.org/10.1073/pnas.0812874106)

Yang G, Bibi S, Du M, Suzuki T \& Zhu MJ 2017 Regulation of the intestinal tight junction by natural polyphenols: a mechanistic perspective. Critical Reviews in Food Science and Nutrition $\mathbf{5 7}$ 3830-3839. (https://doi.org/10.1080/10408398.2016.1152230)

Yoshida H, Miura S, Kishikawa H, Hirokawa M, Nakamizo H, Nakatsumi RC, Suzuki H, Saito H \& Ishii H 2001 Fatty acids enhance GRO/CINC-1 and interleukin-6 production in rat intestinal epithelia cells. Journal of Nutrition 131 2943-2950. (https://doi.org/10.1093/ jn/131.11.2943)

Zelante T, Iannitti RG, Cunha C, De Luca A, Giovannini G, Pieraccini G, Zecchi R, D’Angelo C, Massi-Benedetti C, Fallarino F, et al. 2013 Tryptophan catabolites from microbiota engage aryl hydrocarbon receptor and balance mucosal reactivity via interleukin-22. Immunity 39 372-385. (https://doi.org/10.1016/j.immuni.2013.08.003)

Zhang W, Tang Y, Huang J, Yang Y, Yang Q \& Hu H 2020 Efficacy of inulin supplementation in improving insulin control, HbA1c and HOMA-IR in patients with type 2 diabetes: a systematic review and meta-analysis of randomized controlled trials. Journal of Clinical Biochemistry and Nutrition 66 176-183. (https://doi.org/10.3164/ jcbn.19-103)

Zhao ZH, Xin FZ, Xue Y, Hu Z, Han Y, Ma F, Zhou D, Liu XL, Cui A, Liu Z, et al. 2019 Indole-3-propionic acid inhibits gut dysbiosis and endotoxin leakage to attenuate steatohepatitis in rats. Experimental and Molecular Medicine 51 1-14. (https://doi.org/10.1038/s12276-0190304-5)

Zheng Y, Valdez PA, Danilenko DM, Hu Y, Sa SM, Gong Q, Abbas AR, Modrusan Z, Ghilardi N, de Sauvage FJ, et al. 2008 Interleukin-22 mediates early host defense against attaching and effacing bacterial pathogens. Nature Medicine 14 282-289. (https://doi.org/10.1038/ nm1720)

Zhong H, Ren H, Lu Y, Fang C, Hou G, Yang Z, Chen B, Yang F, Zhao Y, Shi Z, et al. 2019 Distinct gut metagenomics and metaproteomics signatures in prediabetics and treatment-naïve type 2 diabetics. EBiomedicine 47 373-383. (https://doi.org/10.1016/j. ebiom.2019.08.048) https://joe.bioscientifica.com

https://doi.org/10.1530/JOE-20-0473 (c) 2021 Society for Endocrinology Published by Bioscientifica Ltd. Printed in Great Britain 
Zhou X, Han D, Xu R, Li S, Wu H, Qu C, Wang F, Wang X \& Zhao Y 2014 A model of metabolic syndrome and related diseases with intestinal endotoxemia in rats fed a high fat and high sucrose diet. PLOS ONE 9 e115148. (https://doi.org/10.1371/journal. pone.0115148)

Zierer J, Jackson MA, Kastenmüller G, Mangino M, Long T, Telenti A, Mohney RP, Small KS, Bell JT, Steves CJ, et al. 2018 The fecal metabolome as a functional readout of the gut microbiome. Nature Genetics 50 790-795. (https://doi.org/10.1038/s41588-018-0135-7) Zou J, Chassaing B, Singh V, Pellizzon M, Ricci M, Fythe MD,

Kumar MV \& Gewirtz AT 2018 Fiber-mediated nourishment of gut microbiota protects against diet-induced obesity by restoring IL-22-mediated colonic health. Cell Host and Microbe 23 41.e4-53.e4. (https://doi.org/10.1016/j.chom.2017.11.003)

Received in final form 13 November 2020

Accepted 7 December 2020

Accepted Manuscript published online 9 December 2020
(C) 2021 Society for Endocrinology Published by Bioscientifica Ltd. 